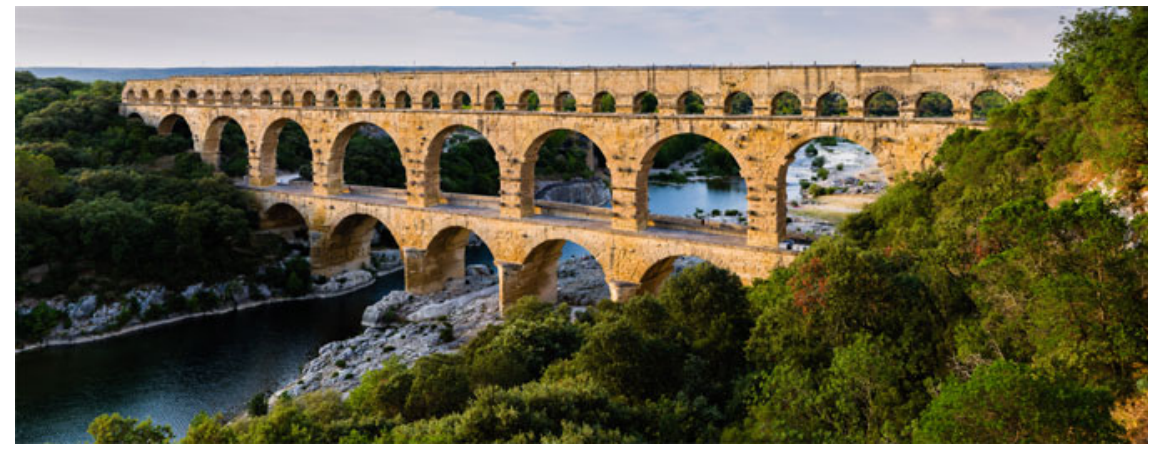

Large-scale water infrastructure above the ground such as the Pont du Gard, France, Wikimedia, Benh LIEU SONG, released under a Creative Commons Share-Alike 3.0 license 


\title{
Chapter 2 \\ Silent and Unseen: Stewardship of Water Infrastructural Heritage
}

\author{
Meisha Hunter Burkett
}

\begin{abstract}
Historic waterworks, including aqueducts and sewers, are civil engineering achievements with unique heritage management challenges. Often designed to be silent and unseen, the subgrade and inaudible infrastructure that delivers water and removes waste is frequently ignored by the public unless it stops working. Although these systems can benefit from official designation as heritage, they are infrequently given this benefit, as the water and wastewater management community that is responsible for them often remains disconnected from the heritage management community. I argue for the establishment of best practice guidelines on the stewardship of historic waterworks infrastructure. Further, I examine the need to evaluate historic significance and identify character-defining features as well as to promote rehabilitation, redundancy, and sustainability of active elements. This discussion is illustrated by the cases of the Aqua Virgo and the Cloaca Maxima of Ancient Rome, the karez of China's Turpan Province, the Jerome Park Reservoir and Water Tunnel No. 3 in New York City, and the mamanteo canals of Peru. In addition, I recommend strongly that water and wastewater managers and preservationists consider adaptive use of historic waterworks infrastructure after they are decommissioned from active use. Vibrant examples of repurposing are included from around the world, including subgrade sewers, cisterns, and weirs, as well as above-grade gatehouses, wastewater treatment plants, and pumping stations. The heroic civil engineering achievements of the past were often realized amidst the need for social change. In particular, water infrastructure systems, such as gravity-fed aqueducts, delivered reliable sources of potable water to communities while also consistently reducing outbreaks of disease and fire. Preservation of this heritage poses multiple challenges, owing, in part, to the inaudibility and invisibility of these systems, the general public's limited awareness of this heritage's civil engineering significance, underrepresentation in World Heritage listings, and limited funding from government agencies that often privilege utility over aesthetics. Although it is inextricably linked to cultural, agrarian, industrial, and maritime landscapes in urban and rural communities worldwide, this infrastructural heritage can suffer unsympathetic alteration, encroachment, obsolescence, demolition, and abandonment. Nonetheless, some waterworks heritage has
\end{abstract}

Meisha Hunter Burkett $(\bowtie)$

Li/Saltzman Architects, New York, USA

e-mail: meishahunter@me.com

(C) The Author(s) 2020

C. Hein (ed.), Adaptive Strategies for Water Heritage,

https://doi.org/10.1007/978-3-030-00268-8_2 
been preserved within active systems, and some decommissioned sites have successfully been repurposed. All merit closer study by modern planners, engineers, and policymakers as they work to meet water delivery and wastewater removal needs today. In regulatory and political climates where heritage is increasingly threatened, there is a need for management guidelines for historic waterworks infrastructure, in order to consistently apply best practices to analysis, decision making, and modes of treatment. Conservation must be balanced with the demand for new construction and upgrades, in a process that (1) acknowledges significance and identifies characterdefining features; (2) evaluates the choice between rehabilitation and replacement for prudence and feasibility; (3) views preservation as a pragmatic and cost-effective means to extend purpose-built service life; (4) replaces sacrificial elements; and (5) repurposes decommissioned elements.

Keywords Historic water and wastewater infrastructure - Heritage management Stewardship guidelines $\cdot$ Rehabilitation $\cdot$ Sustainability $\cdot$ Adaptive use

\section{What Is Water Infrastructural Heritage?}

Civil infrastructure has been described as the "skeletal and vascular framework that supports social, economic, and cultural life in modern civilization" (Sparrow 2001). Water, wastewater, and sewer systems are frequently linear by design; that is to say, a linear relationship can be found between point $\mathrm{A}$ (which might be a dam) and point $\mathrm{B}$ (which could be a distributing reservoir) as well as any interconnective components (such as conduits) located between these points. Water infrastructure includes active water supply, wastewater, drainage systems, and decommissioned components. Drinking water systems collect source water from aquifers, groundwater, lakes, and rivers; remove pollutants; and distribute reliable and abundant sources of potable water to communities. Wastewater systems collect used water and sewage, remove contaminants, and discharge clean water back into rivers and lakes for future use. These systems include subgrade components, such as pipes, mains, conduits, weirs, cisterns, and underground as well as above-grade components, such as gatehouses, aqueduct arcades, spillways, reservoirs, pressure-equalizing towers, and bridges.

Most of the drinking and wastewater infrastructure we rely on is silent and unseen, whether they be pipes that deliver water to a faucet or conduits through which sewage and wastewater flow to a plant to be treated. The concept of invisible and inaudible infrastructure is illustrated in a National Geographic cross section of public utility and transportation facilities located under a typical Manhattan street (as shown in Fig. 1) where we see a complex, color-coded sequence of meticulously stratified underground layers representing electrical, phone, cable, Internet, and telecommunications lines as well as water and sewer pipes and subway tunnels. While this level of complexity is most typical of densely developed metropolitan areas, subgrade infrastructure is ubiquitous in communities large and small. 


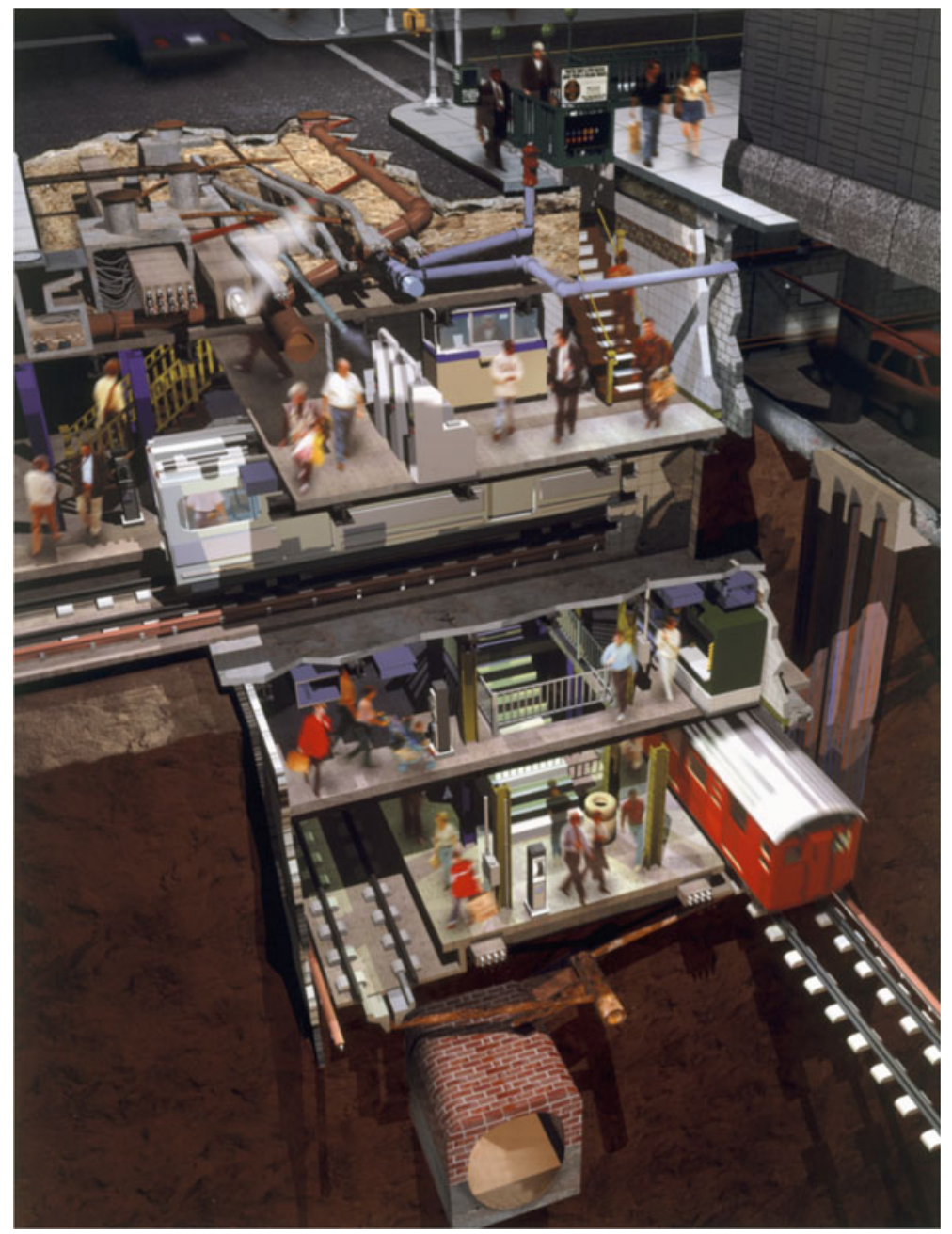

Fig. 1 Axonometric cross section of subgrade infrastructure under a typical Manhattan street. Image courtesy of National Geographic; all rights reserved

Unfortunately, most people in developed countries do not appreciate infrastructure until it is not working. The Columbia University economist Kate Ascher has argued in her book, The Works: Anatomy of a City: "Rarely does a resident of any of the world's great metropolitan areas pause to consider...the myriad systems that operate around the clock to support it...even the most mundane tasks would be impossible without the far-reaching, complex, and often invisible networks of infrastructure that support them" (Ascher 2005). Simply because conduits are not readily accessible or visible, or the water rushing through them is not audible, does not mean the infrastructure is less valuable or significant than a visible bridge might be. 
Historian Rosalind Williams has grappled with the multivalent challenges of confronting underground infrastructure in her book, Notes on the Underground. She observed that "the subterranean environment is a technological one-but it is also a mental landscape, a social terrain, and an ideological map" (Williams 1990, p. 21). Since so much of our water and wastewater infrastructure is invisible and inaudible, an "out of sight, out of mind" predicament can result that inevitably affects public consciousness, diminishes awareness of engineering and architectural significance, dampens political will, and limits funding appropriations. Admittedly, it is not easy to bridge the gap between recognizing the intrinsic engineering, scientific, aesthetic, and social values of historic waterworks and allowing this heritage to perform a didactic, public service function amid the very real challenges of managing water systems as cultural heritage. It is difficult for the general public and elected officials to value water and wastewater infrastructure that is physically concealed, publicly inaccessible, or silent by design. This problem is compounded by the general public's perception that there is a physical disconnect between underground and above-grade components within active water systems. In addition, decommissioned elements are physically disconnected from active systems. Moreover, in heritage management jurisdictions, wide disparities within the same water system can be found in which some elements may benefit from heritage designation and others do not. Abovegrade elements, such as reservoirs, spillways, and bridges, are most easily observed and inventoried for historic landmark designation and heritage protection. It is the underground elements, like water tunnels, that are less frequently seen and less often inventoried or protected.

Of course, heritage protection in and of itself does not guarantee funding for, or conservation of, the protected resource. The American Society of Civil Engineers (ASCE), Congressional Budget Office, the Environmental Protection Agency (EPA), the Harvard School of Public Health, and the Water Infrastructure Network have all prepared independent studies that forecast investments needed for future maintenance and expansion of our nation's water and wastewater infrastructure. ASCE's 2017 Infrastructure Report Card awarded the US water infrastructure a D rating and estimated that one hundred fifty billion dollars will be needed by 2025 to address deficient conditions (Fig. 2). On World Water Day 2016, the EPA announced that two hundred twenty-seven billion dollars would be needed to replace thirty to sixty million miles of lead pipe. This state of affairs is in force while, every year, actual spending falls short of capital needs by many billions of dollars.

Since ongoing maintenance of infrastructure has often not been a priority, deferred maintenance has accelerated the decline of aging systems (Schrader 2011; Milman 2016). Elected officials have resisted committing funds to infrastructure projects that cannot be seen by constituents. Roy Sparrow, a professor of public management at New York University, posited that committing government dollars to improvements invisible and inaccessible to the public is politically unpopular: "I can't recall any politician who ran successfully on the issue of infrastructure" (Sullivan 1998). Despite endemic political unpopularity and funding shortfalls-along with existential and physical challenges-the need for prudent water infrastructure management remains. 
Fig. 22017 ASCE

Infrastructure Report Card, Water and Wastewater Investment Needs 2016-2025. Image courtesy of the American Society of Civil Engineers; released under a Creative Commons Attribution-

NonCommercial-

NoDerivatives 4.0

International License

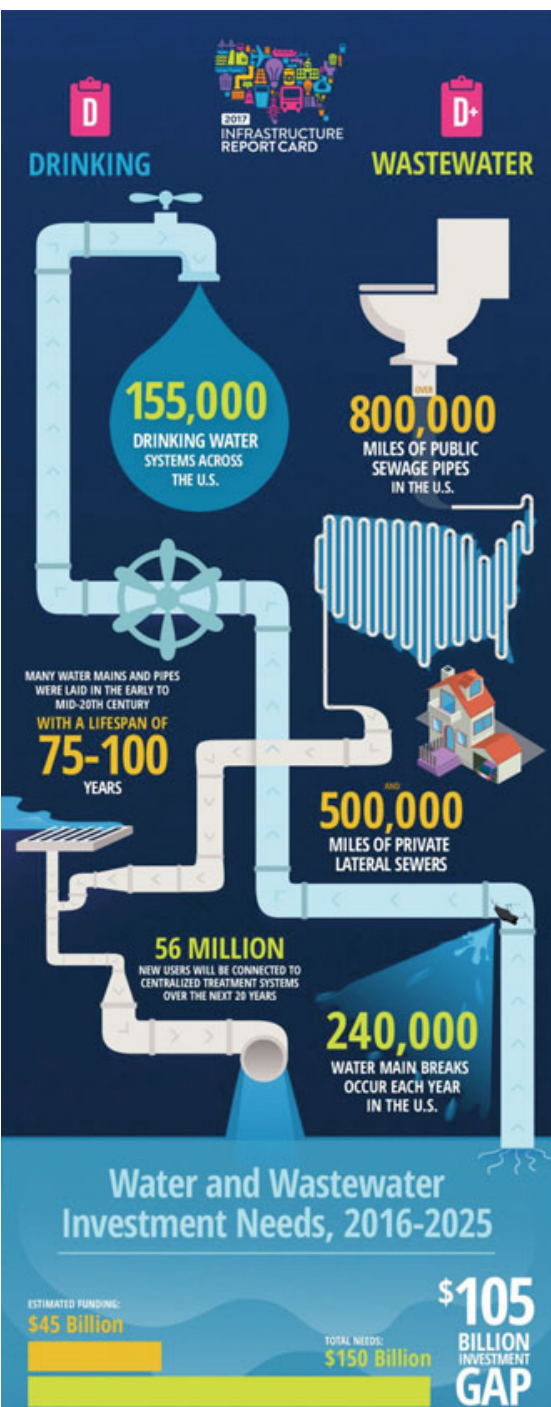

Solutions to Raise the Grades

REINVIGORATE THE STATE REVOLVING LOAN FUND (SRF) PROGRAM

FULIY FUND THE WATER INFRASTRUCTURE FINANCE AND INNOVATION ACT (WIFIA) AT ITS AUTHORIZED LEVEL.

PRESERVE TAX EXEMPT MUNICIPAL BOND FINANCING TO PROVIDE COMMUNITIES WITH AFFORDABLE ACCESS TO CAPITAL FOR WATER INFRASTRUCTURE 


\section{Historic Significance}

The authors of the 2007 Guidelines for Historic Bridge Rehabilitation and Replacement state that, "the first step...that will underlie all planning and preliminary engineering assessments, is to understand why a bridge is historic" (Harshbarger et al. 2007, p. A-8). Understanding the significance of a historic resource is essential to assessing potential impacts to character-defining features; evaluating appropriate, feasible, and prudent treatment options to address those impacts; and making informed decisions that promote long-term stewardship.

It is instructive for twenty-first-century water and wastewater managers, among others, to consider the architectural, engineering, and social significance of ancient Roman potable water and sewer infrastructure, as well as the links between that infrastructure and politicians. Two thousand years ago, ancient Roman engineers designed aqueducts with gravity-fed delivery from source to terminus in cost-effective and militarily defensible underground conduits. Pragmatic engineering design and construction techniques, durable materials selection, and regular maintenance protocols of aqueducts and sewers were intended to offer maximum longevity and utility. Both aqueduct bridges carrying water aloft on monumental arcades and exuberant terminus fountains were often the dramatic, and purposefully visible landmarks, of a much longer, silent, and unseen underground delivery system. Likewise, visible outlets, provided by sewers such as the Cloaca Maxima, did not immediately reveal the extensive, unseen expanses of underground conduits that received and conveyed wastewater and sewage to the outlets.

The journalist Oliver Schwaner-Albright's thesis, that "the history of civilization is the history of infrastructure," underscores the fact that it was Rome's aqueducts and sewers that permitted the residential population of the ancient capital to swell to in excess of one million inhabitants-a number which was unsurpassed in the world until the nineteenth century (Schwaner-Albright 2008). Integrated infrastructure and urban planning provided the substantive building blocks for rational, high-density development (Boatwright 2000; Brunn 1991; Hodge 1992). Rome's aqueducts and sewers served the empire's capital as essential civic utilities that sustained a high quality of life, allowed for in-house plumbing, and fed numerous bathing complexes, fountains, and pools.

The Aqua Virgo (built from 25 BCE to 19 BCE), financed by the consul, statesman, general and architect Marcus Vipsanius Agrippa (63 BCE-12 BCE), exemplifies how an aqueduct could serve as a vehicle for driving political agendas (Nicolazzo 1998; Rinne, Katherine Wentworth. Aqua Urbis Romae: The Waters of the City of Rome. http://www.iath.virginia.edu/rome). The formal termini of the Virgo were the Thermae Agrippae, public baths, and the adjacent Stagnum Agrippae, an artificial pool, located roughly three blocks south of the Pantheon; all of these commissions were financed by Agrippa. The Virgo's terminus was strategically chosen: it was no accident that the aqueduct arrived at the massive bathing complex to which Augustus (63 BCE-14 CE) instituted free public access in $12 \mathrm{BCE}$ and which shared the same piazza as the voting porticoes in the Campus Martius (Platner 1929; Aicher 
2004). Water infrastructure in Rome was a powerful vehicle for promoting political ambitions, spreading propaganda, and obtaining political currency.

Today, the ancient Aqua Virgo (later, renamed the Acqua Vergine) and the Cloaca Maxima continue to operate in their purpose-built uses and are protected cultural heritage monuments (Frontinus 1925; Rinne, Katherine Wentworth. Aqua Urbis Romae: The Waters of the City of Rome. http://www.iath.virginia.edu/rome). The aqueduct and sewer heritage fall under the jurisdiction of the Ministry for Cultural Affairs (Sopraintendenza per I Beni e l'Attivita Culturali), which acts at both the municipal and regional levels. A ministry office, Ufficio Vincoli, administers rightof-way protection (vincolo di rispetto) for the subterranean aqueduct's substructure and superstructure. ACEA SpA (Azienda Comunale Energia e Ambienti) manages the aqueducts and sewers of the Municipality of Rome. Water, wastewater, and sewer operations were first entrusted to ACEA SpA in 1985 (for wastewater treatment service) and 2002 (for sewers), in accordance with the provisions of the Galli Law, national law 36/1994 (Drusiani et al. 2014). Considered together, these monuments are physical reminders of the former empire's engineering, construction, and maintenance capabilities, and vast geographical presence. While cultural heritage and water, wastewater, and sewer management fall under separate agency jurisdictions, the Cultural Affairs Ministry and the ACEA SpA water authority jointly collaborate and promote the preservation, utility, and longevity of the eternal city's water and sewer infrastructure.

Just as bridge engineers begin evaluating the significance of a historic bridge by asking "Why is this bridge historic?" water and sewer managers may ask, "Why is this aqueduct or sewer historic?". We can follow the trajectory of questioning and probe further, asking, "What is this site trying to teach us?". If ancient Roman aqueducts and sewers were a means for achieving political currency two thousand years ago, the preservation of this heritage amplifies our understanding of the actors who designed, built, and maintained these systems. Arguably, the propagandistic lessons of Ancient Rome can also motivate modern political actors to renew our infrastructure today.

\section{Character-Defining Features}

Identifying character-defining features, those visual aspects and physical features that individually and cumulatively help to define the distinctiveness of a historic resource, is a critical second step in heritage protection. The National Park Service's Preservation Brief 17 discusses how to identify and evaluate character-defining features (Nelson 1988). These can include style, typology, structural system, materials, craftsmanship, finishes, details, spaces, site, and setting.

The ancient water canals and wells of Turpan, China, known as karez, merit consideration in a discussion of character-defining features and hydraulic heritage stewardship (Fig. 3). The karez, consisting of a two-thousand year-old, gravity-fed irrigation system dug into the Tianshan Mountains and is connected by underground tunnels and at-grade canals, have sustained grape growers, goat-herders, and silk 


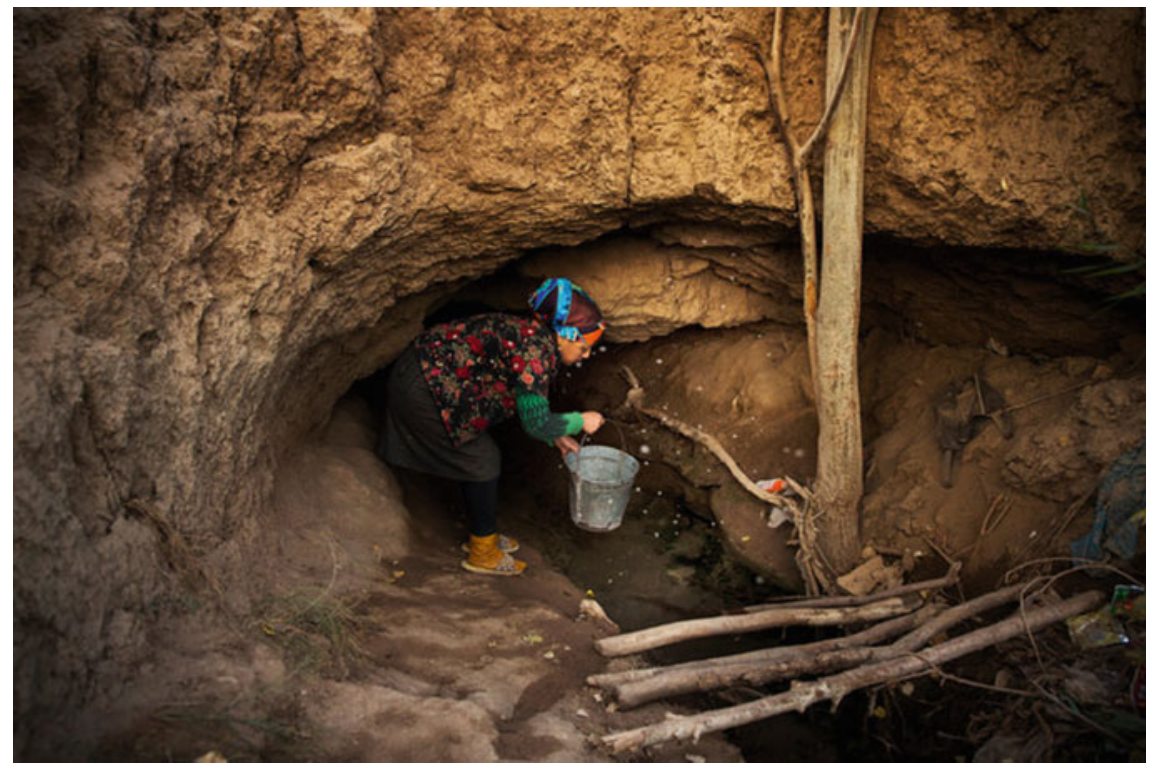

Fig. 3 Collecting water from a karez water channel in Turpan, China; ADAM DEAN/The New York Times/Redux; all rights reserved

road traders with essential glacial runoff in this harsh climate. Character-defining features of the karez include interconnected components such as underground channels, vertical wells, small reservoirs, and open-air canals. The underground channel is the principal watercourse of the system and links the glacial runoff with the Turpan Basin's inhabitants. Vertical wells allow removal of debris. Small reservoirs or outlets (known as dragon mouths) connect the underground channels with the open-air canals. Water empties into the small reservoirs before entering the canals.

The technology of the karez is not exclusive to the Turpan region; in fact, it may have been developed during the Islamic Umayyad Empire in Spain (where karez were known as mayrit or galleria) and subsequently exported to other countries where variants were adapted to the geology and hydrology of individual regions. While known as karez in Afghanistan, Central Asia, Iran, northwest China, and Pakistan, they are also known as qanat in Arabic, falaj in Oman, foggara in Egypt, Libya and Algeria, ghayl or miyan in Yemen, khettara in Morocco, and qanat Romani in Syria (Caponetti 2016).

The Water Resources Department of Xinjiang Uyghur Autonomous Region is responsible for maintaining the karez, controlling water development and usage, and regulating the construction of new wells (Hungshi Chao, personal communication, 2017). In 2006, the karez were designated a Major Historical and Cultural Site protected at the national level by the State Administration of Culture Heritage (SACH), the heritage administrative department of the State Council of the People's Republic of China. According to the department's Web site, the SACH's mission includes 
identifying and protecting relics as well as drafting and enforcing preservation legislation (http://www.english.cach.org.cn). In 2008, the karez of Turpan (in Xinjiang Uyghur Autonomous Region) were added to China's World Heritage watch list and have been enumerated on UNESCO's World Heritage tentative list (UNESCO).

Unfortunately, the karez are vanishing; the potable water itself is also disappearing from the area and its irrigation system is drying up (Jacobs 2016). Industrial scale agribusiness and petroleum companies in this arid region have met their demand for water by drilling their own wells, annually taking three million cubic meters (one hundred six million cubic feet) of water from the region's aquifer. These new wells, as well as electrical water pumps, have disrupted the historic balance of freshwater access, lowered the water table precipitously, and rendered seventeen hundred karez defunct since the 1950s. Cumulatively, these actions threaten the way of life in the region, because the glacial runoff cannot reach the communities who rely on it. While several hundred karez remain in operation, others continue to run dry each year or are contaminated by petroleum and abandoned. Small-scale farmers whose local karez have dried up must buy lesser quality water than the karez water; others fight over the limited water that is available (Sulaiman 2017; Jacobs 2016).

Several modern campaigns have attempted to renew the karez. In 2007, China's national government committed RMB 20M (\$2.9 million) to renovate approximately 100 karez, which was approved by the National Development and Reform Commission of the State Council (NDRC). The NDRC's goals are enumerated in fifteen points, covering a broad spectrum of topics from the economic system's restructuring to environmental sustainability (http://www.en.ndrc.gov.cn). Two of the Commission's goals are relevant to the Tupan karez project: "to approve, authorize, and review key construction projects" and "to participate in the formulation of plans for ecological improvement and environmental protection" (http://www.en.ndrc.gov. $\mathrm{cn})$. Unfortunately, the nationally-funded campaign used inappropriate concrete and metal materials, which compromised the karez' authenticity (Sulaiman 2017). In response, the Cultural Relics Department of Turpan City Government partnered with local craftspeople to restore the karez using traditional conservation methods. Between 2009 and 2016, SACH invested RMB 93 million to conserve one hundred sixty karez, which has increased the quantity of potable water (Hungshi Chao, personal communication, 2017). Despite this success, some Chinese officials have expressed resignation that the extinction of the karez system is inevitable (Jacobs 2016).

\section{Guidelines}

As the Turpan karez example demonstrates, even if historic water infrastructure is recognized and protected, tremendous obstacles to heritage stewardship can still exist. Heritage protection without preservation management can result in damage and decay to historic monuments, including waterworks infrastructure. Moreover, heritage protection in and of itself does not ensure the preservation of natural resources 
(as in potable water, for example) or the sustainability of purpose-built use. While designation represents a significant part of the preservation planning process, formal protection in and of itself does not address the fundamentally difficult topic of managing change to historic infrastructure systems in active use or planning for the adaptive use of decommissioned historic elements. When undertakings that affect historic waterworks are planned, and no preservation goals are set for the project, inappropriate treatment decisions and alteration campaigns may have far-reaching adverse consequences.

Since many of the world's water supply and drainage systems include aging and modern components, water managers must decide what to retain, what to replace, and what to decommission as they plan for the future sustainability of these systems. At present, there are no clear, consistent guidelines to assist water and wastewater managers in assessing the feasibility and prudence of rehabilitation versus replacement or in addressing the post-9/11 necessity of redundancy. Furthermore, there are no industry standards for guiding water managers in the potential adaptive use of water infrastructure that has already been, or is anticipated to be, decommissioned. While multiple reports on water and wastewater systems governance, historic bridge management, industrial heritage conservation, and infrastructure recycling are informative, few specifically tackle the issue of managing change to active and decommissioned historic waterworks infrastructure. Arguably, the most relevant document, authored jointly by water management and preservation agencies, is the Memorandum of Agreement Concerning the Continued Operation of Jerome Park Reservoir (MOA). The Commissioner of the Office of Parks, Recreation, and Historic Preservation of New York state, the New York State Historic Preservation Officer, and the New York City Department of Environmental Protection (DEP) Commissioner executed the Memorandum regarding the operation of the reservoir as a historic facility in active use for New York City's water supply. The MOA is a rare example of a management tool that balances water management needs with preservation concerns.

The Jerome Park Reservoir, which holds five hundred million gallons of water, was originally constructed between 1895 and 1906 at the southern confluence of the Old and New Croton aqueducts; it currently functions as a balancing reservoir for incoming water collected from the upstate Croton watershed, which supplies 10 percent of the City's water. In 1994, the New York State Historic Preservation Office (SHPO) determined it to be eligible for listing on the New York State and National Registers of Historic Places. After sixteen years of discussions between SHPO and DEP about the consequences of listing an operable reservoir within an active water supply system as a historic resource, DEP agreed to list the site on the State and National Registers in 2000. That year, New York State Office of Parks, Recreation, and Historic Preservation, SHPO, and DEP executed the Memorandum of Agreement for the Jerome Park Reservoir. Since 2015, water from the reservoir has been pumped upstream to the $\$ 3.2$ billion Croton Filtration Plant, after which it is distributed to neighborhoods in the Bronx and Manhattan.

The Memorandum defines future DEP undertakings that will either (1) trigger or (2) be exempt from SHPO review and approval. Undertakings that do not require SHPO review will exempt the DEP from certain regulatory compliance requirements. 
As enumerated in the MOA, exempt undertakings include essential repair and in-kind replacement activities, emergency response, selective demolition, upgrades, and new construction that will not compromise character-defining features of substructure and superstructure components.

As a working agreement between the three agencies over the Reservoir's future water and heritage governance, the MOA evidences a spirit of cooperation and pragmatism; it recognizes the DEP's current and future needs to "rehabilitate, modify, upgrade, expand and/or make additions" (MOA, p. 1) to the Reservoir complex while respecting the engineering and architectural significance of the site. After almost twenty years of the MOA's execution, engineers at the DEP's Bureau of Engineering, Design, and Construction involved with projects at the Reservoir and the Croton system had a positive assessment of the SHPO coordination during the design and permitting process, and of their working relationship in general. The DEP's Assistant Commissioner for Intergovernmental Affairs stated that, "Based on the MOA, the [engineers] would provide information on the work scope for these projects which would be endorsed by SHPO, and then follow the MOA to provide notifications on the progress of their design and construction work. The [engineers] followed guidelines for record keeping for these projects and provided this information as requested by SHPO. They did not regard the experience as burdensome in any way" (Mario Bruno, personal communication, 2017). The DEP's optimistic appraisal of the MOA and SHPO, expressed by the water management agency itself, could encourage water managers elsewhere to be more willing to allow heritage designation and inter-agency collaborative management agreements on the future stewardship of historic yet operable water infrastructure. The Jerome Park MOA and other examples of collaboration between water managers and heritage stewards are notable; however, there is a tremendous and persistent need for partnerships of this kind to become more commonplace in the future.

\section{Rehabilitation and Redundancy}

Investing in rehabilitation of historic water infrastructure can be a cost-effective means of tapping extant but deteriorated networks to meet modern needs, at the same time, extending service life and utility, as cases in Rome and Lima illustrate. With sufficient investment, water managers can acknowledge the vast portfolio of extant water infrastructure that exists, as well as the enormous investment in embodied energy that this heritage represents.

In the post-war decade between 1955 and 1965, Rome's ACEA SpA surveyed and repurposed the Aqua Virgo's twenty-one kilometer (thirteen-mile), gravity-fed, masonry-lined conduit or speccus (shown in Fig. 4). In the years following World War II, unregulated residential construction above the aqueduct-and the associated absence of wastewater utilities-resulted in soil contamination, environmental degradation, infiltration, and structural damage which degraded the aqueduct's water to non-potable status (ACEA SpA personal communication, 2007). In 1975, ACEA 

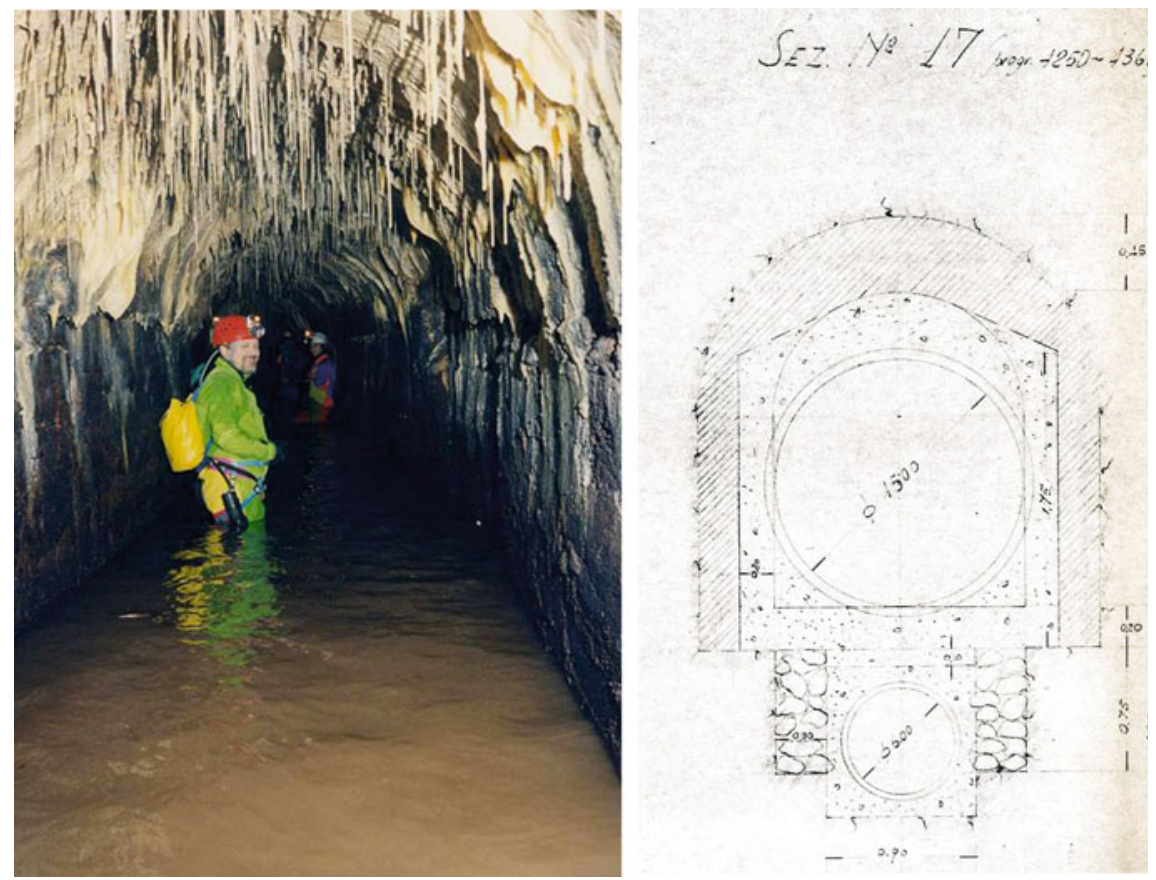

Fig. 4 Inspection of tunnels (left) and section illustrating concrete intubation (intubazione) reinforcement in deteriorated segments of the speccus (right). Image courtesy of Roma Sotteranea and ACEA SpA; released under a Creative Commons Attribution-NonCommercial-NoDerivatives 4.0 International License

was entrusted with the task of expanding service to illegal settlements in peri-urban areas (the borgate), an important contribution to Rome's sustainable development (Lobina 2005). Instead of abandoning or demolishing the aqueduct, ACEA structurally reinforced failed segments of the aqueduct's subterranean tunnels by intubating them with cement tubes (a technique known as intubazione) and repurposed the aqueduct's water for ornamental fountain displays and irrigation of public parks (Nicolazzo 1998).

In Peru, scientists are working to restore the ancient, but largely abandoned, canal systems called mamanteo that are thought to pre-date the Incan empire, in an effort to address Lima's increasing water shortage (Collyns 2015; Schatz 2015). In the mamanteo system, the drainage system funnels hydrological runoff from highland streams into a mountain, where the water percolates through cracks and aquifers to emerge in springs and natural reservoirs (shown in Fig. 5). The mamanteo canals are protected heritage. According to the country's General Law on Cultural Heritage (Article 6 of Law 28296, 2004), the canals are archaeological heritage owned and managed by the Peruvian State. More specifically, the mamanteo canals are defined as archaeological landscape heritage and are protected both for their original purposebuilt use and for their integrity (Brunke, personal communication, 2017). Peru's 


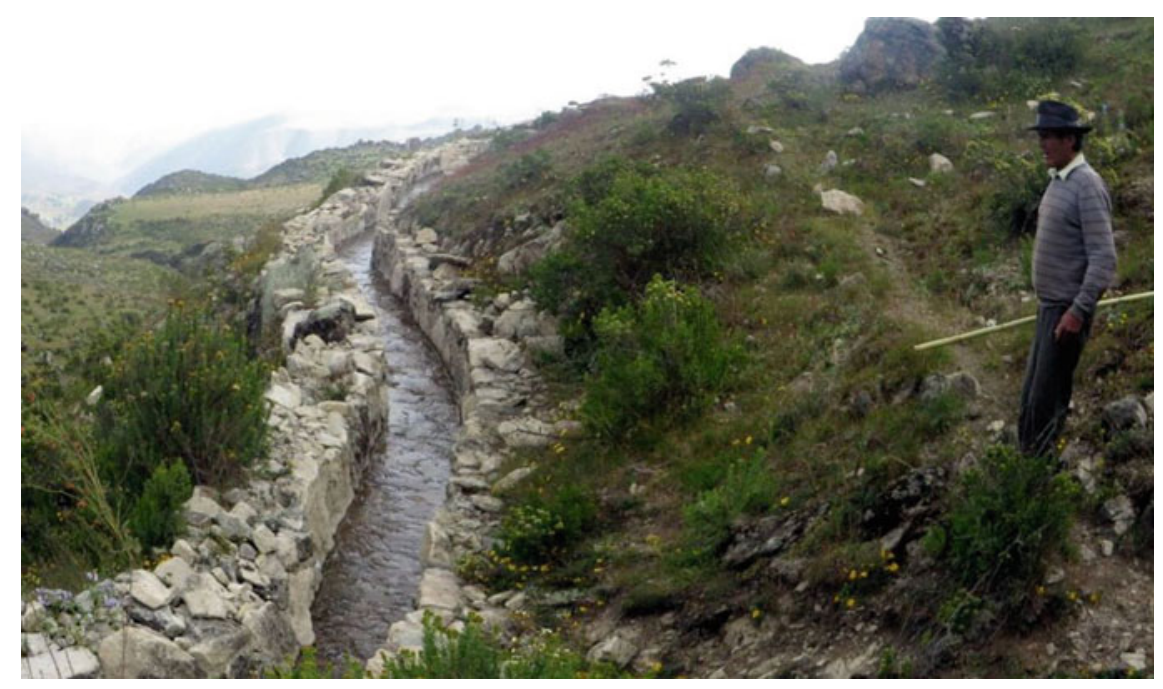

Fig. 5 Detail view of ancient mamanteo canal, part of a network restoration project being undertaken by SUNASS in Peru. Image courtesy of Leah Bremer/The Natural Capital Project; released under a Creative Commons Attribution-NonCommercial-NoDerivatives 4.0 International License

constitution asserts national sovereignty over all sub-grade and above-grade heritage sites of any size, type, or age within the national territory (Silverman, 2006, p. 60).

Re-grouting, de-silting, and performing other maintenance on the canals to restore mamanteo to service may lead to weeks or months of long delays in the delivery of water to end users. However, allowing more time for wet-season moisture to percolate through the mountainous highlands (at a height of three thousand five hundred feet above sea level) is advantageous, particularly during the dry season when water supplies are scarce. By slowing water delivery during the dry season, user communities will receive reliable supplies of water for longer periods of time. Significantly, the proposed restoration project is also cheaper to realize than building a new canal.

The project, which began in March 2015, is funded by the national water regulator SUNASS as part of an investment of 7 million Peruvian Soles (\$21.5 million) in green infrastructure. The work to be conducted also includes recuperating highland wetlands, adapting to climate change, and performing disaster risk mitigation. The campaign is anticipated to increase Lima's water rate by a least one cubic meter per second (Collyns 2015).

In addition to rehabilitation, sustainability upgrades to water infrastructure such as system-wide redundancy and resilient materials can address maintenance issues. They can also address security requirements. In New York, the completion of City Tunnel No. 3 will provide redundancy to the water system and cause the Department of Environmental Protection to temporarily close two existing tunnels (built in 1917 and 1936, respectively) for inspections and repairs for the first time (http://www. PlaNYC-NYC.gov). The Tunnel, the largest capital construction project in New York 
City's history at a cost of $\$ 5$ billion, is to be completed in the 2020s. In a post $9 / 11$ era, actively protecting against terror attacks and integrating redundancy is essential for life-sustaining utilities such as water delivery and sewers.

\section{Adaptive Use}

Although many civic water infrastructure systems built by earlier generations were envisioned to provide many years of useful service, they are not, sui generis, immortal. At a certain point, water managers may indeed choose replacement and decommissioning over rehabilitation. In some cases, entire water and sewer infrastructure systems can be decommissioned from their purpose-built use.

Once they no longer serve their original use, decommissioned water infrastructure components can be adaptively, and creatively, reused, sometimes becoming iconic cultural heritage tourism destinations. Hydraulic infrastructural heritage poses unique challenges for repurposing. Not least among these are finding appropriate new users and programs, performing code-compliance upgrades, and balancing new interventions with respect for historic character-defining features. Several examples of adaptive use of below-grade components, such as cisterns, sewers, and waste weirs, illustrate how decommissioned heritage can be vibrant magnets for cultural heritage tourism.

The Basilica Cistern (dating from $542 \mathrm{CE}$ ), in Istanbul's Eminonu district, originally supplied water for the city during the reign of the Emperor Justinian I. It features three hundred thirty-six marble columns and cloister vaults, as well as a firebrick perimeter wall pointed with hydraulic mortar. After cleaning the site and constructing a walking platform above the water level, the city repurposed the cistern as an exhibition gallery. In Houston, the Cistern at Buffalo Bayou Park, (constructed in 1926 and decommissioned in 2007) was repurposed according to the design of architecture and engineering firm page and reopened to the public in 2016. The forest of columns in the underground space visually recalls the Basilica Cistern in Istanbul. Similarly, the Musée des Égouts de Paris occupies a segment of a decommissioned nineteenth-century sewer. This underground museum has informative exhibits about the city's urban planning history and the essential role played by its sewer system. In Vienna, where the chase scene in the 1948 suspense film, The Third Man (starring Orson Welles) was shot on location in the city's underground sewers, today, visitors can tour a segment of the sewers, known as the "city beneath the city." There, they can learn about Vienna's wastewater and sewer system (shown in Fig. 6). Finally, there is the case of the Egyptian revival style Ossining Waste Weir, built from 1881 to 1886 in Westchester County, New York and finally decommissioned in 1965. A weir chambers, formerly used to ventilate and divert water from the aqueduct when the water level was too high, have been turned into a publicly accessible tour site along the Old Croton Aqueduct State Historic Park.

Some instances of superstructure adaptive use include museums and performing arts venues in former gatehouses, wastewater treatment plants, and pumping stations. 


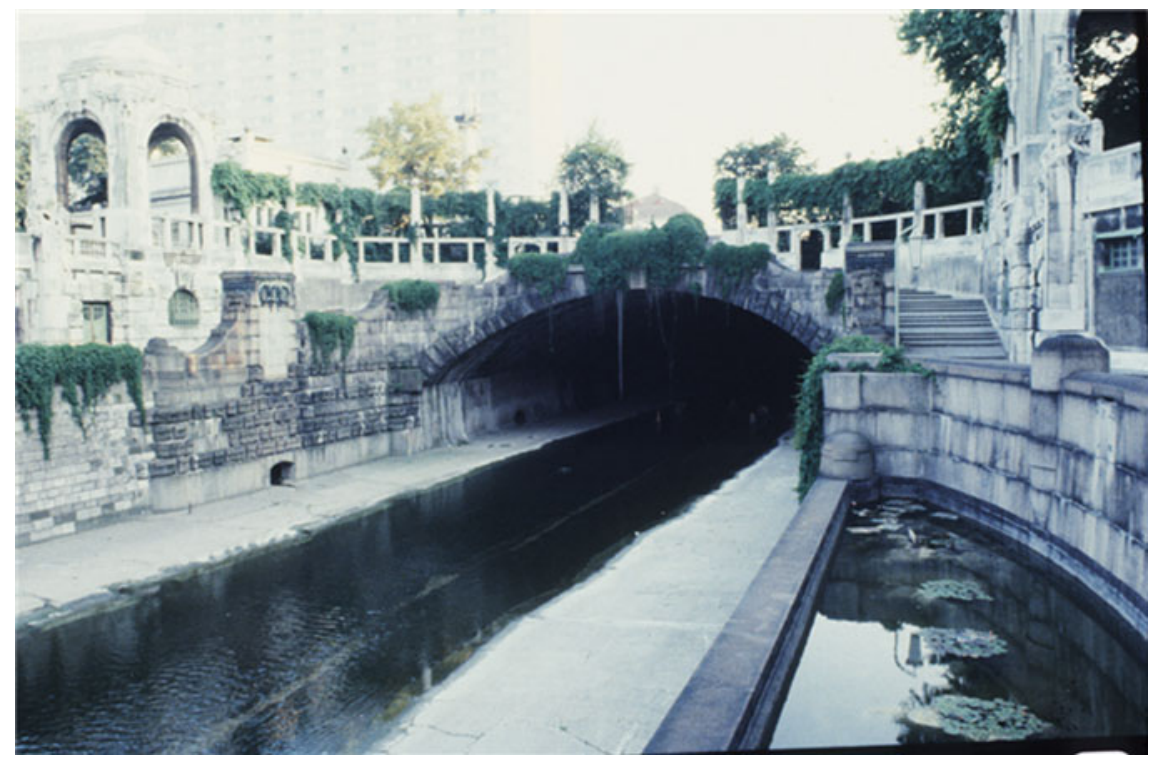

Fig. 6 At grade view of the Vienna River adjustments (Wienflußregulierung), including a partial view of the subterranean passage. Image courtesy of Axel Föhl; released under a Creative Commons Attribution-NonCommercial-NoDerivatives 4.0 International License

The former Croton Aqueduct 135th Street Gatehouse in New York (engineered by Frederick S. Cook, 1887) sat empty for decades before Olhausen Dubois Architects and WASA Studio redesigned the building in 2007 as an award-winning performing arts venue known as Harlem Stage. Similarly, the Museum in Altes Wasserwerk, Berlin (built by Henry Gill and Richard Schultze from 1889 to 1893), once one of the largest and most modern waterworks in Europe, was repurposed as a water museum (Berliner Wasserbetriebe 1993). The former Wastewater Treatment Plant in Prague-Bubeneč (the work of William Henry Lindley and constructed from 1900 to 1906) offers tourists an opportunity to learn about Prague's sewerage and wastewater treatment history as well as its industrial architecture. Decommissioned in 1967, the plant previously served seven hundred thousand residents and is the oldest preserved facility of its kind in Europe. The former Ryhope Pumping Station (the work of Thomas Hawksley, 1868) previously supplied water to the Sunderland area of Great Britain. Decommissioned in 1967, the site was repurposed as the Ryhope Engines Museum and is a Grade II listed building (Föhl 1985). The former Metropolitan Waterworks' high-service pumping station in Boston (originated by Arthur Vinal, 1885-1887 and expanded by Edmund Wheelwright, 1897-98) was recently opened as the Waterworks Museum. The World Heritage listed Woudagemaal (built 1920) is the only steam-powered pumping station in the world that is still in use and features interactive exhibits (Fig. 7). The Fairmount Water Works in Philadelphia (built from 1799-1801; redesigned by John Davis and Frederick Graff in 1811) were repurposed 


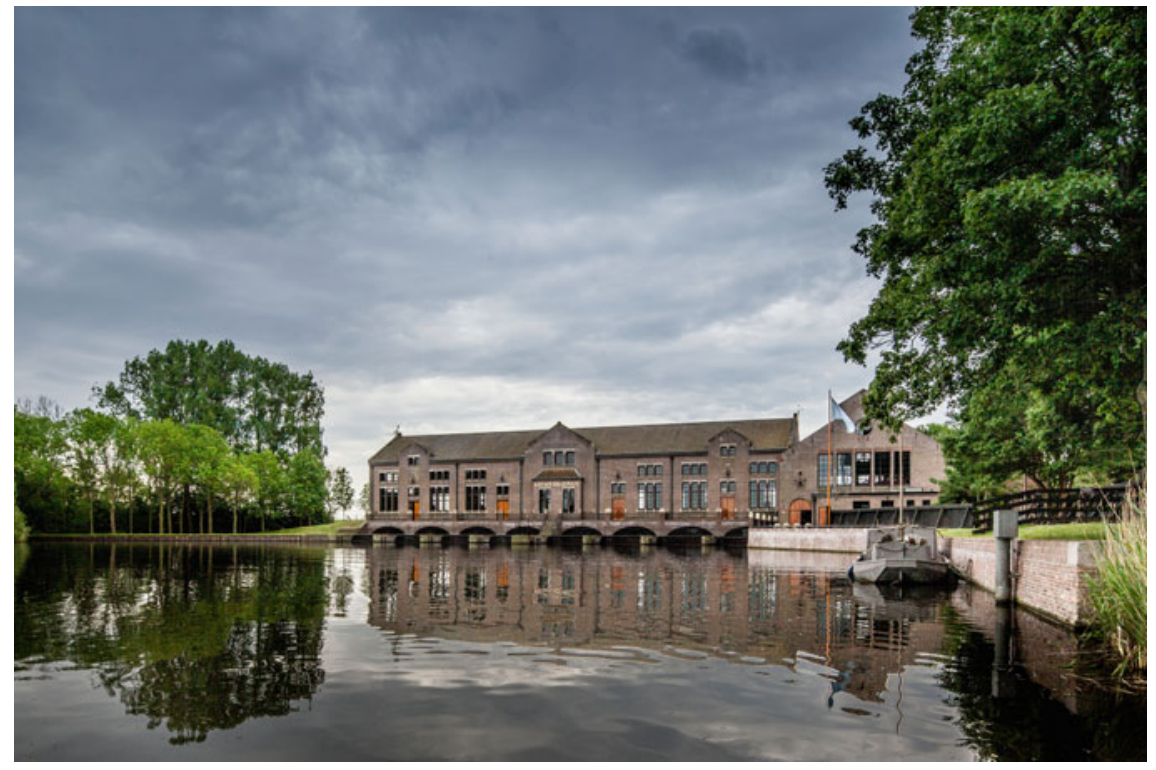

Fig. 7 View of the World Heritage listed steam pumping station (Woudagemaal) in the city of Lemmer, the Netherlands. Image courtesy of Daniel Hartog; all rights reserved

by Philadelphia's Department of Environmental Protection as an interactive water and wastewater history museum.

\section{Future Currents}

Our Common Future, the report of the United Nations World Commission on Environment and Development, defines sustainability as, "Meeting the needs of the present without compromising the ability of future generations to meet their own needs" (United Nations 1987). The examples described in this chapter have demonstrated that historic, gravity-fed delivery infrastructure can be a cost-effective means for meeting modern day consumption and irrigation needs; that investing in the rehabilitation of historic water infrastructure can extend its service life and utility; that upgrades to historic water infrastructure systems are viable; and that decommissioned waterworks can be adaptively and successfully used for cultural heritage tourism. As individual water management authorities and preservation agencies have enjoyed limited successes in managing change to their own water and sewer infrastructure, why can we not aggregate these examples, evaluate them, and discern best practices that can guide decision making in the future? The stewardship of water infrastructural heritage can be part of a cohesive, civic planning framework for new construction, preservation, and repurposing that ultimately promotes consistent decision-making, 
economic viability, environmental sustainability, infrastructural resiliency, and cultural authenticity.

Acknowledgements The author is indebted to Lisa Ackerman (Interim Chief Executive Officer, World Monuments Fund); Albert Appleton (Senior Fellow, The Cooper Union Institute for Sustainable Design); Mario Bruno (Assistant Commissioner, Intergovernmental Affairs, NYC DEP); Andrew Burdick (Architect and Design Strategist, Macquarie Group); Lorenzo Caponetti (Casa Caponetti); Hunghsi Chao (Program Associate for Chinese Projects, World Monuments Fund); Axel Föhl (retired State Officer for the Preservation of Industrial Monuments in Germany); Juan Pablo de la Puente Brunke (former Viceministro de Patrimonio Cultural e Industrias Culturales, Peru); Andrew Potts, Esq. (retired Partner, Nixon Peabody); Christina Rasmussen (US Army Corps of Engineers, New York District); Professor Ethel Sheffer (Columbia University GSAPP); my husband, Morgan, and my family for their encouragement and support. The author's participation in the Water and Heritage for the Future Conference was funded by US/ICOMOS; however, the views and opinions expressed herein do not necessarily reflect those of US/ICOMOS or any other person or entity.

\section{References}

ACEA SpA (2007) Personal communication with the author

Aicher P (2004) Rome alive: a source guide to the ancient city, vol 1. Bolchazy-Carducci

American Society of Civil Engineers Infrastructure Report Card: http://www. infrastructurereportcard.org/

Ascher K (2005) The works: anatomy of a city. The Penguin Press, New York

Basilica Cistern. Istanbul. http://www.ibb.gov.tr/SITES/KS/EN-US/1-PLACES-TO-GO/ MUSEUM/Pages/basilica-cistern.aspx

Berliner Wasserbetriebe (1993) Wasserwerk Friedrichshagen, Industriedenkmal und Versorgungsbetrieb 1893-1993. Berlin/München

Boatwright MT (2000) Hadrian and the cities of the Roman Empire. Princeton University Press, Princeton

Brunke P (2017) Personal communication with the author

Brunn C (1991) The water supply of the ancient Rome: a study of roman imperial administration. The Finish Society of Sciences and Letters, Helsinki, Rome

Bruno M (2017) Personal communication with the author

Caponetti L (2016) The invisible landscape: The Etruscan Cuniculi of Tuscania as a determinant of present-day landscape and a valuable tool for sustainable water management. In: Christian, Stump D (eds) The Oxford handbook of historical ecology and applied archaeology, Isendahl

Chao H (2017) Personal communication with the author.

Collyns D (2015) Peru harnesses ancient canal system to tackle Lima water shortage. The Guardian, June 22

Department of Environmental Protection. City Tunnel Number 3 website: http://www.nyc.gov/html/ dep/html/dep_projects/cp_city_water_tunnel3.shtml

Drittmanntour. Vienna. https://www.drittemanntour.at/de/der-wiener-kanal/geschichte

Drusiani R et al (2014) Evolution of sanitation services in the city of Rome between urban development and environmental quality. In: Angelakis A (ed) Evolution of sanitation and wastewater technologies through the centuries. IWA Publishing, London

Environmental Protection Agency Water Infrastructure and Resiliency Finance Center. https://www. epa.gov/waterfinancecenter

Fairmount Water Works Museum. http://fairmountwaterworks.org

Föhl A (1985) Die Industriegeschichte des Wassers, Düsseldorf 
Frontinus SJ (1925) De Aqueductu Urbis Romae (Trans. C. E. Bennett). Loeb Classical Library, Boston

Harlem Stage. New York. http://harlemstage.org/about

Harshbarger JP et al. (Lichtenstein Consulting Engineers, Inc. in association with Parsons Brinckerhoff Quade \& Douglas, Inc.) (2007) Guidelines for historic bridge rehabilitation and replacement, as requested by the American Association of State Highway and Transportation Officials, Standing Committee on the Environment

Hodge T (1992) Roman aqueducts and water supply. Duckworth, London. http://en.ndrc.gov.cn

Institute for Advanced Technology in the Humanities. University of Virginia. Rome Reborn: Thermae Agrippae. http://www.Archive1.village.virginia.edu

Jacobs A (2016) In a parched corner of Xinjiang. Ancient water tunnels are running dry. The New York Times, Sept 21

Lobina E et al (2005) D36: WaterTime case study—Rome, Italy. WaterTime. A research project supported by the European Commission

Metropolitan Waterworks' High Service Pumping Station. Boston. http://waterworksmuseum.org

Milman O (2016) White House enlists private sector for \$4bn upgrade to water infrastructure. The Guardian, March 22

Musée des Égouts. Paris. http://equipement.paris.fr/musee-des-egouts-5059 and https://www. egouts.tenebres.eu/visite.php

National Development and Reform Commission. People's Republic of China

Nelson LH (1988) Architectural character-identifying the visual aspects of historic buildings as an aid to preserving their character. Preservation Brief 17. National Park Service, September

Nicolazzo V (1998) L'Acqua Vergine: E Suoi Acquedotti e le Fontane di Roma Attraverso I Secoli. ACEA, Roma

Ossining Waste Weir. Westchester, New York. http://aqueduct.org/events/old-croton-aqueductossining-weir-tour

People's Republic of China, State Administration on Cultural Heritage. http://english.gov.cn/state council/2014/10/06/content_281474992893400.htm

PlaNYC website. www.nyc.gov/html/planyc/downloads/.../full_report_2007

Platner SB (1929) A topographical dictionary of ancient rome. Thomas Ashby, Oxford (rev)

Rinne KW Aqua Urbis Romae: the waters of the city of Rome. http://www.iath.virginia.edu/rome

Ryhope Engines Museum, United Kingdom. http://www.ryhopeengines.org.uk/index.html

Schatz J (2015) Lima taps ancient Andean canals to help fight its water shortage. PRI, June 22

Schrader G (2011) Developing a new approach to water infrastructure. From the Yale program on strategies for the future of conservation as presented in the "How can conservation organizations help development go where it should?" Report of the 2011 Berkeley Workshop

Schwaner-Albright O (2008) Design challenge: fend off disaster. The New York Sun, July 22

Silverman H (2006) Cultural resource management and heritage stewardship in Peru. CRM J Heritage Stewardship 3(2) Summer

Sparrow R (2001) The evolving knowledge and skill requirements of America's civil infrastructure managers. Public Works Management and Policy, April 1

Sulaiman E (2017) Exploitation puts ancient well system at risk in Uyghur Region. Tuidang, May 7 (used by permission of Radio Free Asia)

Sullivan J (1998) Study puts a high price on fixing a crumbling city. The New York Times, Aug 25

The Cistern at Buffalo Bayou Park, Houston. https://buffalobayou.org/visit/destination/the-cistern/

UNESCO Tentative World Heritage Lists. http://whc.unesco.org/en/tentativelists/5347/

United Nations (1987) Report of the world commission on environment and development: our common future

Wastewater Treatment Plant in Prague-Bubeneč. http://www.prague.eu/en/object/places/623/oldwastewater-treatment-plant-in-bubenec-stara-cistirna-odpadnich-vod-v-bubenci?back=1

Williams R (1990) Notes on the underground: an essay on technology, society, and the imagination. MIT Press, Cambridge 
Meisha Hunter Burkett is senior preservationist at Li/Saltzman Architects and a recipient of the NEA Rome Prize (Historic Preservation) from the American Academy in Rome. She has contributed to Water Industry as World Heritage (The International Committee for the Conservation of Industrial Heritage, 2018), L'aque, le Pietri e Bronzi le Fontane Monumentali (Commune di Roma, 2012), City Secrets: Rome (Fang, Duff Kahn, 2011), and Sustainability and Historic Preservation: Toward a Holistic View (University of Delaware Press, 2011).

Open Access This chapter is licensed under the terms of the Creative Commons AttributionNonCommercial-NoDerivatives 4.0 International License (http://creativecommons.org/licenses/bync-nd/4.0/), which permits any noncommercial use, sharing, distribution and reproduction in any medium or format, as long as you give appropriate credit to the original author(s) and the source, provide a link to the Creative Commons license and indicate if you modified the licensed material. You do not have permission under this license to share adapted material derived from this chapter or parts of it.

The images or other third party material in this chapter are included in the chapter's Creative Commons license, unless indicated otherwise in a credit line to the material. If material is not included in the chapter's Creative Commons license and your intended use is not permitted by statutory regulation or exceeds the permitted use, you will need to obtain permission directly from the copyright holder.

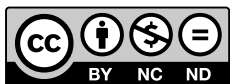

